
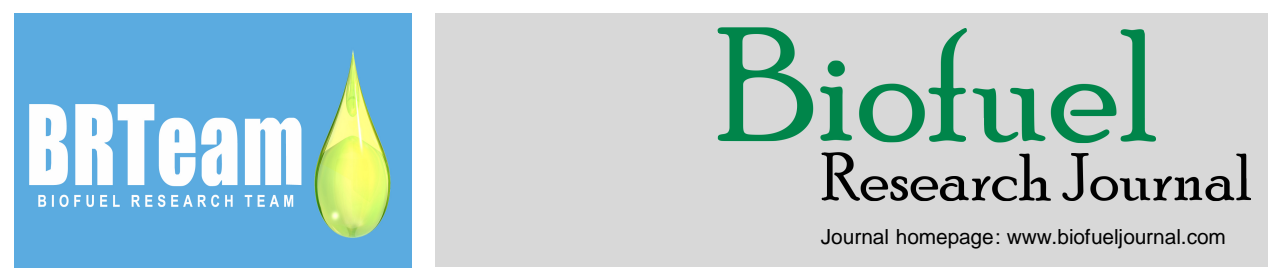

Original Research Paper

\title{
Anaerobic treatment of agro-industrial wastewaters for COD removal in expanded granular sludge bed bioreactor
}

Abumalé Cruz-Salomón ${ }^{1,2, *}$, Edna Ríos-Valdovinos ${ }^{1, *}$, Francisco Pola-Albores ${ }^{3}$, Rocío Meza-Gordillo², Selene LagunasRivera $^{4}$, Víctor M. Ruíz-Valdiviezo ${ }^{2}$

${ }^{1}$ Facultad de Ingeniería. Universidad de Ciencias y Artes de Chiapas. Libramiento Norte Poniente 1150. Lajas Maciel, Tuxtla Gutiérrez, C.P. 29039, Chiapas, México.

${ }^{2}$ Departamento de Ingeniería Química y Bioquímica, Tecnológico Nacional de México-Instituto Tecnológico de Tuxtla Gutiérrez, Carretera Panamericana Km 1080, Tuxtla Gutiérrez, C.P. 29050, Chiapas, México.

${ }^{3}$ Centro de Investigación y Desarrollo Tecnológico en Energías Renovables, Universidad de Ciencias y Artes de Chiapas, Libramiento Norte Poniente 1150,

Lajas Maciel, Tuxtla Gutiérrez, C.P. 29039, Chiapas, México.

${ }^{4}$ Catedrática CONACYT, Tecnológico Nacional de México-Instituto Tecnológico de Tuxtla Gutiérrez. Carretera Panamericana Km 1080, Tuxtla Gutiérrez,

C.P. 29050, Chiapas, México.

\section{HIGHLIGHTS}

$>$ Anaerobic EGSB bioreactors were successfully performed for treating different agro-industrial wastewaters.

- COD removal of up to 91,74 , and $96 \%$ for cheese whey, vinasse, and coffee-processing wastewater, respectively.

$>\mathrm{CH}_{4}$ yield of 340,245 , and $300 \mathrm{~mL} / \mathrm{gCOD} \cdot \mathrm{d}$ for

cheese whey, vinasse, and coffee-processing

wastewater, respectively.

$>$ Biogas generated contained $63.5,70.8$, and $80.3 \%$

$\mathrm{CH}_{4}$ for cheese whey, vinasse, and coffee-processing

wastewater, respectively.

\section{ARTICLE INFO}

\section{Article history:}

Received 7 July 2017

Received in revised form 24 September 2017

Accepted 16 October 2017

Available online 1 December 2017

\section{Keywords:}

Anaerobic EGSB reactor

Biogas production

Vinasse

Cheese whey

Coffee-processing wastewater

\section{GRAPHICAL ABSTRACT}

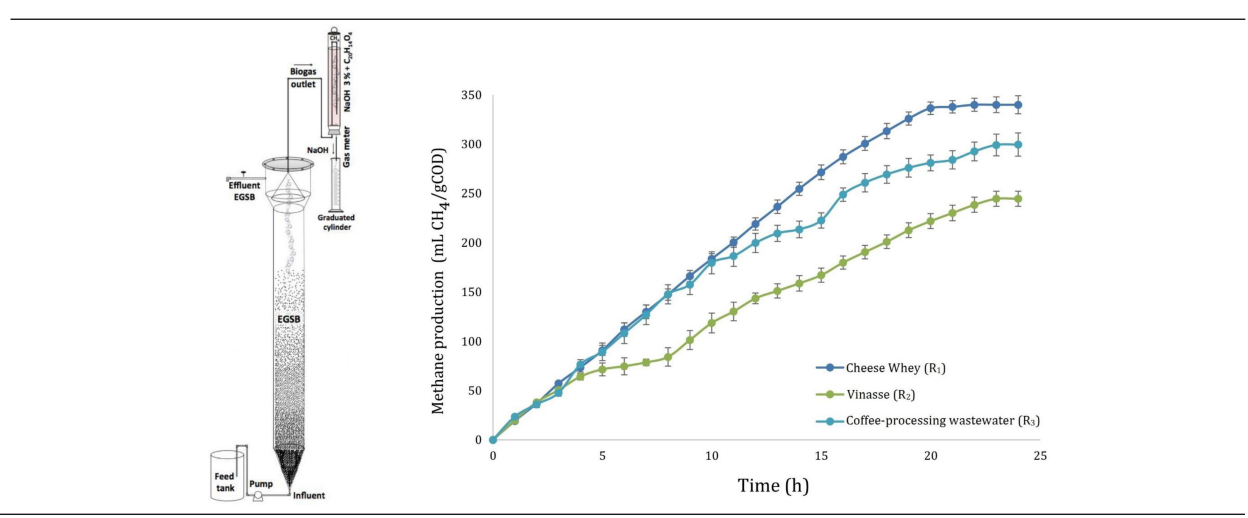

ABSTRACT

Untreated agro-industrial wastewaters are undesirable in the aquatic environment due to the presence of high organic matter contents. However, they may constitute a large potential for biogas production. The present investigation is focused on three laboratory-scale anaerobic expanded granular sludge bed (EGSB) bioreactors, continuously operated for $60 \mathrm{~d}$ under mesophilic condition with the aim of exploring the feasibility of treating three most significant agro-industrial wastewaters in Chiapas, Mexico (i.e., cheese whey, vinasse, and coffee-processing wastewater). The EGSB bioreactors were operated with a hydraulic retention time (HRT) of $6 \mathrm{~d}$ under stable conditions (i.e., buffer index (BI) of 0.31, 0.34, and 0.03), generating a maximum chemical oxygen demand (COD) removal efficiency of 91,74 , and $96 \%$ with an average methane production of 340, 245, and $300 \mathrm{~mL} / \mathrm{g}$ COD$\cdot \mathrm{d}$ for cheese whey, vinasse, and coffee processing wastewater, respectively. According to the obtained results, the EGSB bioreactors could be a sustainable alternative to simultaneously solve the environmental problems and to produce bioenergy.

(c) 2017BRTeam. All rights reserved.

* Corresponding author at: Tel.: +529612368925, E-mail address: dr.abumale @ gmail.com (A.C.S.); Tel.: +529616170440 Ext. 4270, E-mail address: edna.rios@ unicach.mx (E.R.V.)

Please cite this article as: Cruz-Salomón A., Ríos-Valdovinos E., Pola-Albores F., Meza-Gordillo R., Lagunas-Rivera S., Ruíz-Valdiviezo V.M. Anaerobic treatment of agro-industrial wastewaters for COD removal in expanded granular sludge bed bioreactor. Biofuel Research Journal 16 (2017) 715-720. DOI: 10.18331/BRJ2017.4.4.3 


\section{Introduction}

Agro-industries such as cheese factories, distilleries, and coffee plantations represent one of the most important economic activities in Chiapas, Mexico. These industries process agricultural raw and livestock materials generating millions of tons of wastewater and large amounts of by-products, which are much unexploited and in some cases dangerous for the environment (Dareioti et al., 2009). These production facilities are usually scattered throughout the countryside, and the raw materials are processed at different seasonal rates causing significant variations in both quantity and quality of the wastewaters generated during the year.

The most important waste stream of the cheese factories is cheese whey. The characteristics of cheese whey effluents may vary significantly, depending on the final products, system type, and operation methods used in the manufacturing plant (Prazeres et al., 2012). The distillery factories also generate a wastewater called vinasse, containing a variety of organic substances whose composition and characteristics may vary, depending on the feedstock and the process used for distillate production (Robles-González, 2011; RoblesGonzález et al., 2012). The coffee-processing farms generate the coffeeprocessing wastewater, containing organic matters like pectin, proteins, and sugars (Von Enden, 2002). This wastewater can be further reused for depulping of the same day products, but this causes further increase of its organic content and a decrease in $\mathrm{pH}$ (Adams and Dougan, 1987).

It has been well-documented that the wastewaters generated by the abovementioned agro-industries introduce a high concentration of organic pollutants into the environment (De Matos et al., 2001; EPA, 2003; MoEF, 2003; RoblesGonzález et al., 2012). In fact, they could pose serious threats to the surrounding water bodies, aquatic life, and human health if discharged directly into surface waters like rivers, streams or lakes (Haddis and Devi, 2008). Anaerobic digestion in expanded granular sludge bed (EGSB) bioreactors has been proposed as a feasible low cost technology to treat high strength wastewaters, while biogas production from renewable resources could also be targeted (Zhang et al., 2007; Shin et al., 2010).

Therefore, this investigation was focused on simultaneous anaerobic treatment and biogas production from the most significant agro-industrial wastewaters largely found in Chiapas, Mexico, i.e., cheese whey, vinasse, and coffee-processing wastewater using EGSB bioreactors

\section{Materials and methods}

\subsection{Characterization of agro-industrial wastewaters}

Cheese whey was obtained from a cheese-processing factory, whilst vinasse and coffee processing wastewater were obtained from a plant of ethyl alcohol and coffee farm, respectively. The samples were stored at $-20{ }^{\circ} \mathrm{C}$ until used.

The characteristics of the agro-industrial wastewaters such as $\mathrm{pH}$, chemical oxygen demand $(\mathrm{COD})$, biochemical oxygen demand $\left(\mathrm{BOD}_{5}\right)$, sedimented solids, total solids (TS), total volatile solids (TVS), total suspended solids (TSS), floating matter, conductivity, color, turbidity, acidity, alkalinity, total nitrogen, total phosphorus, and sulfates were analyzed according to the Standard Methods for Examination of Water and Wastewater (APHA, 2005). The biodegradability index was calculated according to the formula $\mathrm{BOD}_{5} / \mathrm{COD}$ (Abdalla and Hammam, 2014) and the total organic carbon (TOC) was determined by the method proposed by Walkley and Black (2006). Additionally, density and viscosity were measured using a viscometer (Anton Paar SVM 300) in triplicate.

\subsection{Inoculum}

Granular anaerobic inoculum was obtained from a full-scale upflow anaerobic sludge bed (UASB) bioreactor located at the wastewater plant in Tuxtla Gutiérrez, Chiapas, Mexico. The inoculum was regular and spherical in shape $(\varnothing$, c. $0.5-1 \mathrm{~mm})$ and in a grey-green color with TS and TVS contents of $49.75 \mathrm{~g} / \mathrm{L}$ and $29.5 \mathrm{~g} / \mathrm{L}$, respectively.

\subsection{Bioreactors set up and operation}

The EGSB bioreactors (Fig. 1a) were made of fiberglass with a $3.3 \mathrm{~L}$ working volume, a 15.8 height/diameter ratio, and were inoculated with 1000 $\mathrm{mL}$ ( $30 \%$ of bioreactors working volume) of the mesophilic inoculum. All the three bioreactors, $\mathrm{R}_{1}$ (Cheese Whey), $\mathrm{R}_{2}$ (Vinasse), and $\mathrm{R}_{3}$ (Coffeeprocessing wastewater) were operated at a hydraulic retention time (HRT) of $6 \mathrm{~d}$, but different organic loading rates (OLR) of $7.5 \mathrm{~kg} \mathrm{COD} / \mathrm{m}^{3} \mathrm{~d}\left(\mathrm{R}_{1}\right)$, $5.8 \mathrm{~kg} \mathrm{COD} / \mathrm{m}^{3} \mathrm{~d}\left(\mathrm{R}_{2}\right)$, and $3 \mathrm{~kg} \mathrm{COD} / \mathrm{m}^{3} \mathrm{~d}\left(\mathrm{R}_{3}\right)$ were applied. The bioreactors were automatically fed by a peristaltic pump (Master Flex model 7534-04) and the influents were buffered with $\mathrm{NaOH}$ and $\mathrm{NaHCO}_{3}$.

\subsection{Effluent analyses}

Samples from bioreactors effluents were routinely taken for COD, $\mathrm{pH}$, and temperature measurement according to the Standard Methods for Examination of Water and Wastewater (APHA, 2005). The alkalinity factor was adapted from Speece (1996) according to following procedure: $10 \mathrm{~mL}$ of sample was taken and was acidified to a $\mathrm{pH}$ of 5.75 and the amount of $\mathrm{HCl}(0.1 \mathrm{M})$ required was recorded $\left(\mathrm{V}_{1}\right)$, corresponding to the part alkalinity (PA). Subsequently, the sample was brought to $\mathrm{pH} 4.3$ and the amount of acid required $\left(\mathrm{V}_{2}\right)$ was recorded again, corresponding to intermediate alkalinity (IA) and the total alkalinity (TA) was determined as the sum of both $(\mathrm{TA}=\mathrm{PA}+\mathrm{IA})$. The buffer index $(\mathrm{BI})$ was then calculated by using the following Equation 1:

$$
\mathrm{BI}=\frac{I A}{T A}
$$

Methane production was measured by the Mariotte bottle technique described by Cruz-Salomón et al. (2017), This technique involves the absorption of $\mathrm{CO}_{2}$ present in biogas, using an alkaline liquid $(3 \% \mathrm{NaOH}$ solution) with phenolphthalein as indicator. In order to determine in situ composition of the biogas produced (methane and carbon dioxide), the same technique but with a solution $\mathrm{NaCl}(3 \%)$ and phenolphthalein, coupled to the equipment Sewerin model Multitec 540 (Fig. 1 b) was used (Cruz-Salomón et al., 2017).

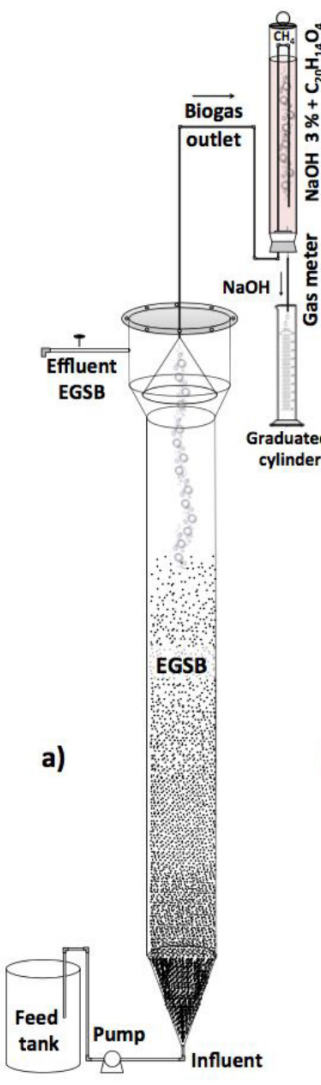

b)

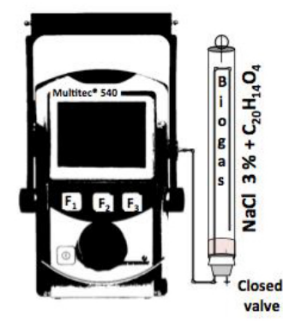

Fig.1. (a) Schematic diagram of the EGSB bioreactor; and (b) Scheme for measuring bioga composition. 


\section{Results and Discussion}

\subsection{Physicochemical characterization of wastewaters}

The results of the physicochemical analysis of the agro-industrial wastewaters are tabulated in Table 1 . It is evident that the investigated wastewaters were heavily polluted with organic loads, nutrients, and suspended matters. Organic load was measured as COD and BOD whilst nutrients were measured as phosphate and nitrate contents.

Table 1.

Physicochemical characteristics of the investigated agro-industrial wastewaters.

\begin{tabular}{|c|c|c|c|}
\hline Parameter & Cheese whey & Vinasse & $\begin{array}{c}\text { Coffee-processing } \\
\text { wastewater }\end{array}$ \\
\hline $\mathrm{pH}$ & 4.44 & 4.53 & 3.95 \\
\hline Color (Pt-Co) & 9366.7 & 68700.3 & 17966.7 \\
\hline Turbidity (NTU) & 416.3 & 1745.7 & 1481.7 \\
\hline Density $(\mathrm{g} / \mathrm{mL})$ & 1.1512 & 1.1667 & 1.1075 \\
\hline Conductivity (mS/cm) & 8.57 & 15.47 & 5.21 \\
\hline Viscosity (mPa.s) & 0.9869 & 1.1301 & 1.0904 \\
\hline Floating matter & $\mathrm{P}$ & NP & NP \\
\hline Acidity $\left(\mathrm{mg} \mathrm{CaCO}_{3} / \mathrm{L}\right)$ & 3313 & 4975 & 3360 \\
\hline $\mathrm{COD}\left(\mathrm{mgO}_{2} / \mathrm{L}\right)$ & 91600 & 71605 & 45955 \\
\hline $\mathrm{BOD}\left(\mathrm{mgO}_{2} / \mathrm{L}\right)$ & 90083 & 54861 & 37944 \\
\hline Biodegradability index & 0.98 & 0.76 & 0.82 \\
\hline Sedimented solids (mL/L) & 15 & 43 & 380 \\
\hline $\mathrm{TS}(\mathrm{g} / \mathrm{L})$ & 47.617 & 64.889 & 19.593 \\
\hline TVS (g/L) & 44.702 & 49.82 & 8.208 \\
\hline TOC $(\mathrm{mg} / \mathrm{L})$ & 33400 & 40400 & 11400 \\
\hline Total phosphorus (mg/L) & 707.43 & 110.41 & 36.43 \\
\hline Total nitrogen $(\mathrm{mg} / \mathrm{L})$ & 2200 & 1600 & 700 \\
\hline $\mathrm{C} / \mathrm{N}$ & $15: 1$ & $25: 1$ & $16: 1$ \\
\hline Total sulfate $(\mathrm{mg} / \mathrm{L})$ & 17 & 360 & 10 \\
\hline
\end{tabular}

Comparing the values of $\mathrm{pH}, \mathrm{BOD}, \mathrm{COD}$, total solids, phosphate, and nitrate for the cheese whey, vinasse, and coffee-processing with the respective permissible limits for effluent discharge set forth by the World Health Organization (WHO) (WHO, 1995), it was found that the values recorded for all these parameters were at concerning levels. These agro-industrial wastewaters can lead to several serious environmental pollution impacts like anoxia, eutrophication, death of aquatic life, and many severe health problems, if directly discharged into the water bodies without prior treatment (De Matos et al., 2001; Janczukowicz et al., 2008; Robles-González et al., 2012).

It is known that the organic matters contained in agro-industrial wastewaters can be removed by anaerobic digestion provided that they have specific ratios of nutrients (i.e., $15: 1 \geq \mathrm{C} / \mathrm{N} \leq 30: 1$ ) and high biodegradability index (i.e., $>0.3$ ). When the biodegradability index is less than 0.3 , the substrate is not suitable to carry out anaerobic digestion because it does not have enough biodegradable organic matters (Aguirre, 2004). The biodegradability index calculated were $0.98,0.76$, and 0.82 for cheese whey, vinasse and coffee-processing, respectively, marking these agro-industrial wastewaters are excellent substrates to be treated by anaerobic digestion.

The efficiency and stability of treatment depends mostly on the composition $(\mathrm{C} / \mathrm{N})$ and the nature of the used agro-industrial wastewaters (Sitorus et al., 2013). High $\mathrm{C} / \mathrm{N}$ ratio is an indication of a rapid consumption of nitrogen by the microbial population involved in the process and may lead to a slow microbial growth due to subsequent nitrogen deprivation. On the other hand, low $\mathrm{C} / \mathrm{N}$ ratios could cause ammonia accumulation, occurrence of $\mathrm{pH}$ values exceeding 8.5 , which are toxic to microbial complexes, and consequently decreased efficiency of organic matter removal (Yen and Brune, 2007; Sitorus et al., 2013). As presented in Table 1, the C/N ratios were $25: 1,15: 1$, and $16: 1$ for vinasse, cheese whey and coffee-processing, respectively. Hence, for all wastewaters investigated, this parameter was also within the optimal level for anaerobic digestion.

Another important variable to be taken into account for the anaerobic treatment of agro-industrial wastewater is $\mathrm{pH}$, as this may affect the efficiency of bioreactors. The optimal $\mathrm{pH}$ is between 5.5 and 6.5 for acidogenic and between 7.8 and 8.2 for methanogenic phases. Therefore, the overall optimal $\mathrm{pH}$ range for microbial anaerobic populations is between 6.8 and 7.4 (Mao et al., 2015) and outside this range, the microbial populations could be inhibited. In this study, the $\mathrm{pH}$ values of the agroindustrial wastewaters were not optimum for anaerobic digestion; and therefore, it was necessary to neutralize them with $\mathrm{NaOH}$ or $\mathrm{NaHCO}_{3}$ before feeding into the bioreactors. Overall and according to their physicochemical profile, the studied agro-industrial wastewaters could be regarded as acceptable candidates for anaerobic treatment using EGSB bioreactors.

\subsection{COD removal}

$\mathrm{R}_{1}, \mathrm{R}_{2}$ and $\mathrm{R}_{3}$ EGSB bioreactors were operated over $60 \mathrm{~d}$ under mesophilic condition. The average temperature of the influents was $21.3 \pm$ $0.5^{\circ} \mathrm{C}$. Figure 2 shows the temperature profile of the effluents leaving the EGSB bioreactors.

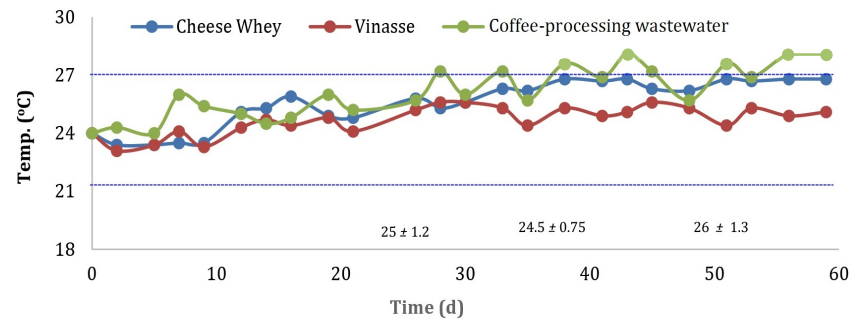

Fig.2. Variations in the temperature of the effluents leaving the EGSB bioreactors. The values shown are the average values with their standard deviations.

The $\mathrm{pH}$ profile in the EGSB bioreactors is presented in Figure 3. Although the $\mathrm{pH}$ of the influents was adjusted at 7 using $\mathrm{NaOH}$, it can be observed that in the first $10 \mathrm{~d}$, the EGSB bioreactors suffered from acidification, but when $\mathrm{NaHCO}_{3}$ was added instead of $\mathrm{NaOH}$, the $\mathrm{pH}$ of the bioreactors approached favourable conditions for anaerobic bacteria as reported by Mao et al. (2015).

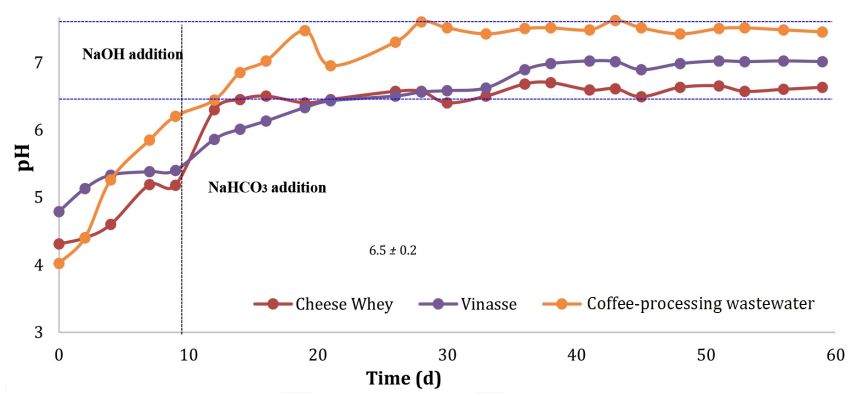

Fig.3. Variations in the $\mathrm{pH}$ of the effluents of the EGSB bioreactors. The values shown are the average values with their standard deviations. 
The $\mathrm{pH}$ in the anaerobic bioreactors is a very important factor for the optimal functioning of the system. Maintaining $\mathrm{pH}$ in an appropriate range depends on the buffering capacity of the reactor, i.e., the present alkalinity as well as the concentration of volatile fatty acids (VFAs). The accumulation of VFAs could result in stress conditions in anaerobic processes; thus, it is necessary to avoid their accumulation and the resultant decrease in $\mathrm{pH}$, which could destabilize the system (Martin-Gonzalez et al., 2013).

A simple way to investigate the conditions in an anaerobic system is through determining the alkalinity supplied by the carbonate/bicarbonate groups as nonprotonated forms of VFAs (Londoño and Peñuela, 2015). In this study, the BI was monitored by obtaining the TA, PA, and the IA. The first term is the amount of alkalinity provided by the VFAs and the carbonate/bicarbonate. The second term refers to the alkalinity provided only by the carbonate/bicarbonate. The last term is the difference between TA and PA, is related only to alkalinity provided by VFAs (Björnsson et al., 2001). Figure 4 shows the behavior of these parameters during the processing time. The alkalinity analysis was based on the IA/TA ratio, where the recommended range is 0.2-0.4 to prevent unstable conditions in the system by VFAs accumulation (Rojas, 2004; Pérez and Torres, 2008).

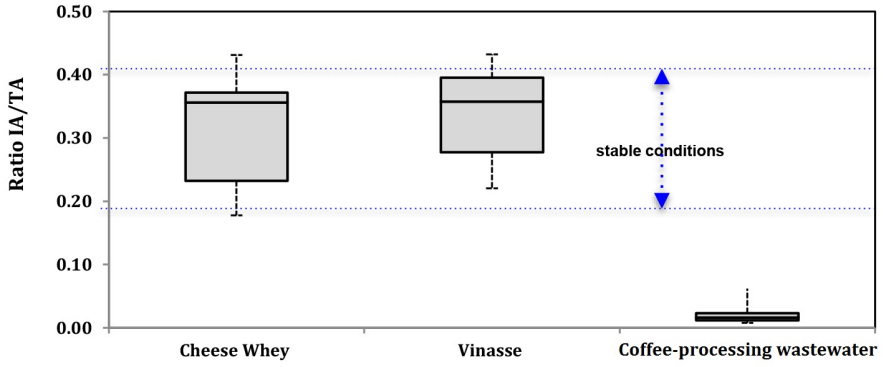

Fig.4. Behavior of the alkalinity factor during the operation of the EGSB bioreactors.

On the other hand, the IA/TA ratio also depends on the type of wastewater, and to achieve a stable process, it needs to be analysed. The IA/TA ratio in the $\mathrm{R}_{1}$ and $\mathrm{R}_{2}$ stood at 0.31 and 0.34 , respectively, revealing stable conditions, similar to the values previously reported by Cruz-Salomón et al. (2017). However, this ratio was recorded at lower than 0.2 for the $\mathrm{R}_{3}$ (i.e., average values of 0.03 ), indicating a potential interference with the buffering capacity of the bicarbonates due to possible VFAs accumulation (Martin-Gonzalez et al., 2013). Nevertheless, the $\mathrm{pH}$ value in the $\mathrm{R}_{3}$ was maintained between 6.5 and 8.0, which showed that no acidification occurred. If $\mathrm{pH}$ is over 7 , the majority of the VFAs are in anionic form as the pK of VFAs is in the range 4.85.0 but when the buffer index is close to zero, then neither anionic nor neutral forms are present. Therefore, a very low buffer index value is indicative of a balanced system without VFA accumulation.

The anaerobic treatment performance in the EGSB bioreactors was determined by monitoring COD removal rates (Figure 5). A dividing line is presented separating the two stages of operation of the bioreactor. The influents were buffered with $\mathrm{NaOH}$ and $\mathrm{NaHCO}_{3}$ in the first and second stages, respectively. As shown in Figure 3, the bioreactors $R_{1}$ and $R_{2}$ tended to acidification, but when they were buffered with $\mathrm{NaHCO}_{3}$ in the second stage, an increase in $\mathrm{pH}$ and better stability of the bioreactors were observed which also led to a more favourable removal of organic matters after $10 \mathrm{~d}$.

Figure 5a presents the trend of organic matter removal efficiency in the $\mathrm{R}_{1}$ bioreactor. More specifically, it can be observed that at the beginning, COD removal efficiency decreased due to the acidification caused by higher VFAs production rate (by acetogenic bacteria) than their consumption rate (by the methanogenic archaea). Gutiérrez et al. (1991) have also made similar observations and alkaline supplementation during the start-up period or during the process has been recommended as a strategy to amend the reactor condition (Rodgers et al., 2004). Following buffering with $\mathrm{NaHCO}_{3}$, a fast pH recovery and increased COD removal were observed. On average, the COD removal efficiency stood at as high as $91 \%$, with the organic matter concentration of the effluent reaching $4105 \mathrm{mg} / \mathrm{L}$.
The $\mathrm{R}_{2}$ bioreactor was operated in a stable and efficient manner throughout the evaluation period (with suing both $\mathrm{NaOH}$ and $\mathrm{NaHCO}_{3}$ ), reaching a COD removal rate of $70 \%$ (Figure $5 \mathrm{~b}$ ). The organic matter concentration of the effluent was recorded at $8683 \mathrm{mg} / \mathrm{L}$. The low removal rate shows that although the EGSB bioreactor was successful in dealing with the degradable fraction of organic matter in vinasse, it failed to to remove the recalcitrant compounds fraction (e.g., brown polymers also known as melanoidins, etc.). Nevertheless, the removal efficiency obtained in this study was slightly higher than the values reported by Qinglin et al. (2012).

Figure 5(c) presents the trend of organic matter removal efficiency in the $\mathrm{R}_{3}$ bioreactor. This bioreactor was also operated in a stable and efficient manner throughout the evaluation period, reaching removal rates as high as 96\%; with the concentration of organic matter in the effluent reaching as low as $694 \mathrm{mg} / \mathrm{L}$. To the best of our knowledge, this is the first report on digesting coffee-processing wastewater using this type of bioreactor, i.e., EGSB.
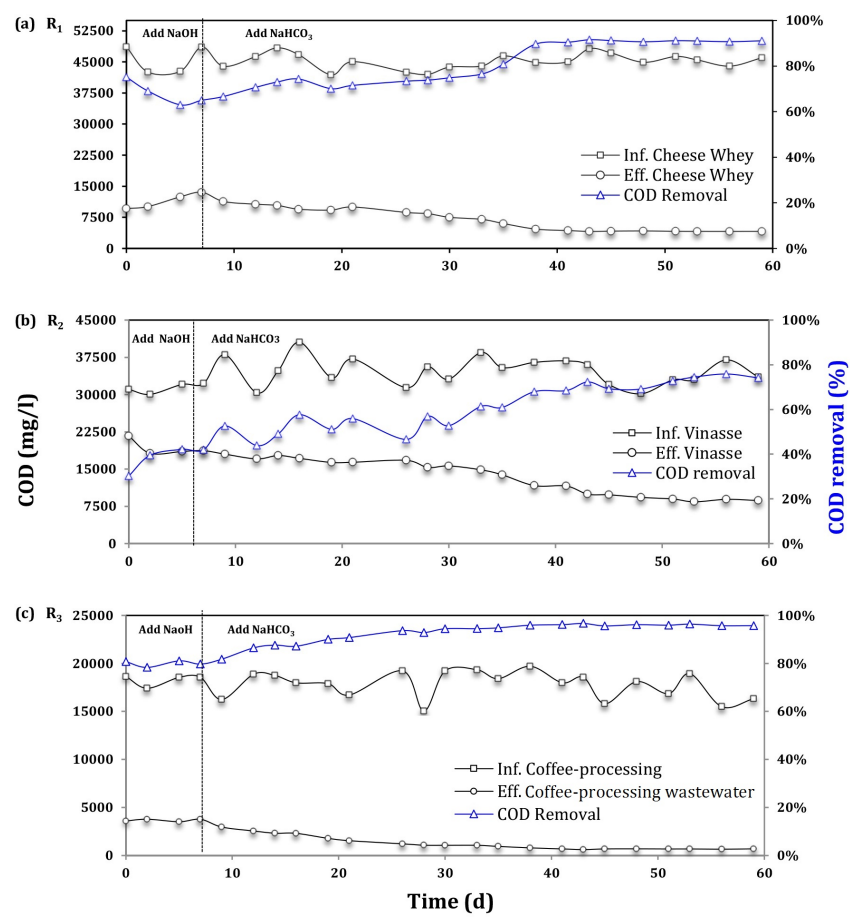

Fig.5. Process performance of the EGSB bioreactors, treating agro-industrial wastewaters at mesophilic range (a) $R_{1}$, (b) $R_{2}$, (c) $R_{3}$.

Data concerning the other parameters, analyzed immediately after the bioreactors reached a balanced condition, are shown in Table 2 .

Overall, the results obtained showed that the bioreactors were operated properly and resulted in high removal efficiency rates. Nevertheless, the effluents generated still contained a large amount of biodegradable organic matter and nutrients necessitating a second anaerobic treatment, advanced oxidation processes, percolating filters or biodiscs to achieve complete removal of biologically-recalcitrant components and to meet the permissible limits by the WHO for discharging such effluents.

\subsection{Methane production}

Over the $60 \mathrm{~d}$ experiment, methane production was measured at 340 , 245 , and $300 \mathrm{~mL} / \mathrm{gCOD} \cdot \mathrm{d}$ for cheese whey, vinasse, and coffee-processing, respectively. Methane production rates showed statistically significant differences $(\mathrm{p}<0.05)$ among different agro-industrial wastewaters. These can be observed in the $24 \mathrm{~h}$ kinetics shown in Figure 6. 
Table 2.

General analysis of the influent and effluent of the bioreactors.

\begin{tabular}{|c|c|c|c|c|c|c|c|c|c|}
\hline \multirow{2}{*}{ Parameters } & \multicolumn{3}{|c|}{ Cheese whey $\left(R_{1}\right)$} & \multicolumn{3}{|c|}{ Vinasse $\left(\mathbf{R}_{2}\right)$} & \multicolumn{3}{|c|}{$\begin{array}{l}\text { Coffee-processing } \\
\text { wastewater }\left(\mathbf{R}_{3}\right)\end{array}$} \\
\hline & Influent & Effluent & $\mathrm{E}(\%)$ & Influent & Effluent & $\mathbf{E}(\%)$ & Influent & Effluent & $\mathbf{E}(\%)$ \\
\hline $\mathrm{COD}\left(\mathrm{mg} \mathrm{O}_{2} / \mathrm{L}\right)$ & 45213 & 4105 & 91 & 34609 & 8683 & 74 & 19855 & 694 & 96 \\
\hline $\mathrm{BOD}_{5}(\mathrm{mg} \mathrm{O} / \mathrm{L})$ & 34101.1 & 4280 & 87 & 26302.8 & 4550 & 82 & 14760 & 620 & 95 \\
\hline $\mathrm{TS}(\mathrm{g} / \mathrm{L})$ & 19.558 & 5.66 & 71 & 32.445 & 12.48 & 62 & 10.795 & 1.46 & 86 \\
\hline Color (Pt-Co) & 4680 & 2547 & 46 & 35333 & 26366 & 25 & 8033 & 1180 & 85 \\
\hline Turbidity (NTU) & 277 & 121.4 & 56 & 721 & 430 & 40 & 677.6 & 67.5 & 90 \\
\hline Phosphorus (mg/L) & 240.6 & 294 & - & 35.2 & 46.1 & - & 18.4 & 32.3 & - \\
\hline Nitrogen $(\mathrm{mg} / \mathrm{L})$ & 1090.8 & 138.3 & 87 & 701.7 & 75.8 & 89 & 310.1 & 18.9 & 94 \\
\hline
\end{tabular}

$\mathrm{E}(\%)=$ Removal Efficiency

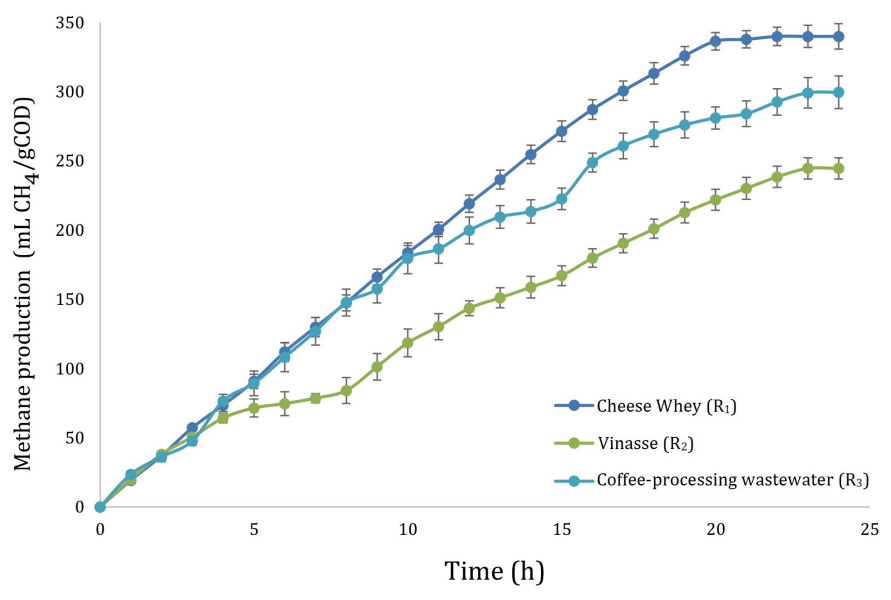

Fig.6. Methane production in the EGSB bioreactors. The values shown are the media average with their standard deviations.

The higher production of methane from cheese whey could be attributed to the fact that this waste stream is a highly biodegradable substrate as reflected in its biodegradability index presented in Table 1 . However, the bioreactor fed with cheese when tended to acidify, and therefore, it was necessary to adjust the condition with a buffer solution (e.g., $\mathrm{NaHCO}_{3}$ ) for better operation. On the other hand, since the bioreactors fed with vinasse and coffee processing, operated under stable condition (no acidification) throughout the experiment, the lower methane production from these waste streams could be justified by their less biodegradable organic matter contents (lower biodegradability index).

The biogas produced by the $\mathrm{R}_{1}, \mathrm{R}_{2}, \mathrm{R}_{3}$ bioreactors contained $63.5,70.8$, and $80.3 \%$ of methane, generating calorific values of $22.80,25.46$, and 28.84 $\mathrm{MJ} / \mathrm{m}^{3}$, respectively (determined at normal conditions). Therefore, since biogas with metahne concentration greater than $45 \%$ is flammable, these products can be considered of fuel value. Accordingly, these agro-industrial wastewaters hold great potentials for bioenergy production, shifting the paradigm of wastewater management from 'treatment and disposal' to 'treatment and beneficial utilization'.

\section{Conclusions}

EGSB bioreactors can be a sustainable alternative to solve the environmental problems generated by agro-industrial wastewater. In the present study, COD removal efficiency $91 \%$ for $\mathrm{R}_{1}$ (Cheese Whey), $74 \%$ for $\mathrm{R}_{2}$ (Vinasse), and $96 \%$ for $R_{3}$ (Coffee-processing wastewater) were achieved. Moreover, this bioreactor type was also proved to be a sustainable alternative for bioenergy production; 340, 245, and $300 \mathrm{~mL} \mathrm{CH} / \mathrm{gCOD} \cdot \mathrm{d}$ with a calorific value of $22.80,25.46$, and $28.84 \mathrm{MJ} / \mathrm{m}^{3}$ from $\mathrm{R}_{1}, \mathrm{R}_{2}$, and $\mathrm{R}_{3}$ waste streams, respectively.

\section{Acknowledgments}

The authors are grateful for the access to the research facilities of the School of Environmental Engineering and the Center for Research and Technological Development in Renewable Energy of the University of Sciences and Arts of Chiapas and the Polo Tecnológico Nacional para el Desarrollo de Investigación y Pruebas Analíticas en Biocombustibles del Tecnológico Nacional de México/Instituto Tecnológico de Tuxtla Gutiérrez.

\section{References}

[1] Abdalla, K.Z., Hammam, G., 2014. Correlation between biochemical oxygen demand and chemical oxygen demand for various wastewater treatment plants in Egypt to obtain the biodegradability indices. Int. J. Sci. Basic Appl. Res(IJSBR) 13(1), 42-48.

[2] Adams, M.R., Dougan, J., 1987. Coffee Technology, John Wiley and Sons. New York.

[3] Aguirre, P., 2004. Removal mechanisms of organic matter and nutrients in subsurface flow constructed wetlands. New criteria for the design and operation of constructed wetlands. CPET. Barcelona. 17-29.

[4] Federation, W.E., American Public Health Association, 2005. Standard Methods for the Examination of Water and Wastewater, $20^{\text {th }}$ ed. American Public Health Association (APHA), Washington, DC, USA.

[5] Björnsson, L., Murto, M., Jantsch, T.G., Mattiasson, B., 2001. Evaluation of new methods for the monitoring of alkalinity, dissolved hydrogen and the microbial community in anaerobic digestion. Water Res. 35(12), 2833-2840.

[6] Cruz-Salomón, A., Meza-Gordillo, R., Rosales-Quintero, A., Ventura-Canseco, C., Lagunas-Rivera, S., Carrasco-Cervantes, J., 2017. Biogas production from a native beverage vinasse using a modified UASB biorreactor. Fuel. 198, 170-174.

[7] Dareioti, M.A., Dokianakis, S.N., Stamatelatou, K., Zafiri, C., Kornaros, M., 2009. Biogas production from anaerobic co-digestion of agroindustrial wastewaters under mesophilic conditions in a twostage process. Desalination. 248(1-3), 891-906.

[8] De Matos, T.A., Lo Monaco, P.A., Pinto, A.B., Fia, R., Fukunaga, D.C., 2001. Pollutant potential of wastewater of the coffee fruits 
processing. Federal University of Viçosa, Department of Agricultural Engineering, Viçosa-MG, Brazil.

[9] Gutiérrez, J.R., Encina, P.G., Fdz-Polanco, F., 1991. Anaerobic treatment of cheese-production wastewater using UASB reactor. Bioresour. Technol. 37(3), 271-276.

[10] Haddis, A., Devi, R., 2008. Effect of effluent generated from coffee processing plant on the water bodies and human health in its vicinity. J. Hazard. Mater. 152(1), 259-262.

[11] Janczukowicz, W., Zieliński, M., Dębowski, M., 2008. Biodegradability evaluation of dairy effluents originated in selected sections of dairy production. Bioresour. Technol. 99(10), 4199-4205.

[12] Londoño, Y.A., Peñuela, G.A., 2015. Anaerobic biological treatment of methylparaben in an expanded granular sludge bed (EGSB). Water Sci. Technol. 71(11), 1604-1610.

[13] Mao, C., Feng, Y., Wang, X., Ren, G., 2015. Review on research achievements of biogas from anaerobic digestion. Renew. Sust. Energy Rev. 45, 540-555.

[14] Martin-Gonzalez, L., Font, X., Vicent, T., 2013. Alkalinity ratios to identify process imbalances in anaerobic digesters treating source-sorted organic fraction of municipal wastes. Biochem. Eng. J. 76, 1-5.

[15] MoEF; Ministry of Environment and Forest, 2003. Water (Prevention and Control of Pollution) Cess (Amendment) Act, 2003. Ministry of Environment and Forests, Government of India, New Delhi.

[16] Pérez, A., Torres, P., 2008. Alkalinity indices for control of anaerobic treatment of readily acidifiable wastewaters. Ing. Compet. 10(2), 41-45.

[17] Prazeres, A.R., Carvalho, F., Rivas, J., 2012. Cheese whey management: a review. J. Environ. Manage. 110, 48-68.

[18] Qinglin, X., Yanhong, L., Shaoyuan, B., Hongda, J., 2012. Effects of ORP, recycling rate, and HRT on simultaneous sulfate reduction and sulfur production in expanded granular sludge bed (EGSB) reactors under micro-aerobic conditions for treating molasses distillery wastewater. Water Sci.Technol. 66(6), 1253-1262.

[19] Robles-González, V., 2011. Integrated treatment of mezcal vinasses for depuration and discharge. Doctoral Thesis. ENCB del IPN. México D.F., México.
[20] Robles-González, V., Galíndez-Mayer, J., Rinderknecht-Seijas, N., Poggi-Varaldo, H.M., 2012. Treatment of mezcal vinasses: a review. J. Biotechnol. 157(4), 524-546.

[21] Rodgers, M., Zhan, X.M., Dolan, B., 2004. Mixing characteristics and whey wastewater treatment of a novel moving anaerobic biofilm reactor. J. Environ. Sci. Health, Part A. 39(8), 2183-2193.

[22] Rojas, O., 2004. La alcalinidad como parámetro de control de los ácidos grasos volátiles en digestores UASB. 101-105.

[23] Shin, S.G., Han, G., Lim, J., Lee, C., Hwang, S., 2010. A comprehensive microbial insight into two-stage anaerobic digestion of food waste-recycling wastewater. Water Res. 44(17), 4838-4849.

[24] Sitorus, B., Sukandar, Panjaitan, S.D., 2013. Biogas recovery from anaerobic digestion process of mixed fruit-vegetable wastes. Energy Procedia. 32, 176-182.

[25] Speece, R.E. (1996). Anaerobic Biotechnology for Industrial Wastewaters. Archae Press, USA.

[26] EPA, 2003. CAFO regulations, Federal Register 68(29).

[27] Von Enden, J.C., 2002. Best practices at wet processing pay financial benefits to farmers and processors. GTZ-PPP Project on Improvement of coffee quality and sustainability of coffee production in Vietnam.

[28] Walkley, A., Black, I., 2006. An examination of the Degtjareff method for determining organic carbon in soils: effect of variations in digestion conditions and of inorganic soil constituents. Soil Sci. 63, 251-263.

[29] WHO, 1995. Guideline for discharge of industrial effluent characteristics. WHO, Geneva. 3, 231-236.

[30] Yen, H.W., Brune, D.E., 2007. Anaerobic co-digestion of algal sludge and waste paper to produce methane. Bioresour. Technol. 98(1), 130134.

[31] Zhang, R., El-Mashad, H.M., Hartman, K., Wang, F., Liu, G., Choate, C., Gamble, P., 2007. Characterization of food waste as feedstock for anaerobic digestion. Bioresour. Technol. 98(4), 929-935. 